\begin{tabular}{|c|c|}
\hline Uniqbu Journal of Social Sciences (UJSS) \\
E-ISSN: 2723-3669
\end{tabular}

\title{
THE IMPLEMENTATION OF PREVIEW, ASK QUESTIONS, READ, AND SUMMARIZE STRATEGY IN READING CLASS: AN ACTION RESEARCH STUDY
}

\author{
(Penerapan Strategi Preview, Ask Questions, Read, and Summarize di Pelajaran \\ Membaca: An Action Research) \\ Vivit Rosmayanti $^{1}$, Hasnani ${ }^{2}$, Monalisa ${ }^{3}$ \\ ${ }^{123}$ Universitas Megarezky \\ Email: vivitoellah@gmail.com
}

(Received 19 December; Revised 26 December; Accepted 30 December 2021)

\begin{abstract}
This research aimed to improve students' reading ability using the PAQRS strategy. This research applied a classroom action research (CAR) design conducted in two cycles consisting of four stages: planning, action, observation, and reflection. Each cycle consists of four meetings. The researcher conducted tests, interviews, and observations in collecting the data. The data is presented quantitatively as the primary and supporting data. The study's findings showed that $18.91 \%$ of students achieved the minimum completeness criteria, and the average score was 67.35 in the first cycle test. While $81.08 \%$ of students achieved the minimum completeness criteria, the average score was 76.72 in the second cycle test. The result of the research indicated that students' achievement is an increase from cycle 1 to cycle 2. This study concludes that the PAQRS strategy can successfully improve students' reading skills.

Keywords: Reading Ability, PAQRS Strategy, Classroom Action Research
\end{abstract}

\begin{abstract}
Abstrak
Penelitian ini bertujuan untuk meningkatkan kemampuan membaca siswa dengan menggunakan strategi PAQRS. Penelitian ini menggunakan desain penelitian tindakan kelas (PTK) yang dilaksanakan dalam dua siklus yang terdiri dari empat tahap yaitu perencanaan, tindakan, observasi dan refleksi. Setiap siklus terdiri dari empat pertemuan. Dalam pengumpulan data, peneliti melakukan tes, wawancara, dan observasi. Data disajikan secara kuantitatif sebagai data primer dan kuantitatif sebagai data pendukung. Hasil penelitian menunjukkan bahwa pada tes siklus I terdapat 18,91\% siswa yang mencapai KKM dan nilai rata-rata 67,35. Sedangkan pada tes siklus II terdapat 81,08\% siswa yang mencapai KKM dan nilai rata-rata 76,72. Hasil penelitian menunjukkan bahwa prestasi belajar siswa meningkat dari siklus 1 ke siklus 2. Kesimpulan penelitian ini adalah strategi PAQRS berhasil meningkatkan kemampuan membaca siswa.
\end{abstract}

Kata Kunci: Kemampuan Membaca, Strategi PAQRS, Penelitian Tindakan Kelas

\section{INTRODUCTION}

Reading is one of the problematic skills in English because it needs hard work from the eyes and brain. According to Zwierz (2004), the purpose of reading is to construct the meaning of a text. On the other hand, reading is how the reader comprehends the meaning of the text. Reading is considered very valuable in the context of foreign language learning because it obtains the 
input language as Mikulechy (2011) pointed out that reading is one of the fundamental ways to improve the students' general language skills in English and help students to obtain their vocabulary, increase reading speed, critical thinking and expend students' knowledge.

Based on curriculum 2013, the teaching of reading is part of the English subject where the aims of teaching reading to gain students comprehend in reading. However, reading is a challenging task for Indonesian students. The objective of teaching reading is to help students comprehend the meaning of the text to produce the main idea and get the purpose of the text.

The guideline of KTSP states that the standard competence of the Senior High School of reading is that students should understand to identify the main point of the paragraph, get the specific information, know the function of the text inference and understand the meaning of the word.

Based on reality, on the examination item, those contents are text. It means that if students did not understand the meaning of the text students would be challenging to finish the examination. When students did not understand the text, they would be missing the communication. On the other hand, comprehending the text is necessary for students. Students' comprehension is too low. It means that the purpose of teaching reading is not achieved yet. On the other hand, the student has the low motivation and a bad habit of reading, especially in Indonesia. According to UNESCO research in 2006, Indonesia's reading interest is at the lowest position at the Asian Educational Achievement.
To solve the students' problem,' a teacher should use an interesting method while learning because the method can cause students to have the low ability. Most Indonesian schools use lecture teaching to instruct students, which has been popular for many years (Rosmayanti \& Yahrif, 2019). According to McIntosh (1996), lecturing is typically a one-way process without debate, questioning, or direct practice, making it a poor teaching style. To improve students' ability in reading, there is a specific method as the alternative way to learn reading. Kung (2019) suggested that teachers raise students' reading strategy awareness by encouraging them to utilize effective reading strategies. In addition, Readers are required to employ different skills and knowledge while reading, which aid them in obtaining textrelated information, such as selecting critical information and main ideas, collecting, organizing, and summarizing information, and correcting comprehension breakdowns (Habók \& Magyar, 2019).

PAQRS strategy is one of the alternative ways to solve students' problems in reading. For that reason, the researcher conducted classroom action research to improve students' reading skills through Preview, Ask Questions, Read, and Summarize (PAQRS) Strategy. The research question of this study is "How is the improvement of students' reading skill by implementing Preview, Ask, Question, Read and Summarize strategy?"

\section{LITERATURE REVIEW}

Reading is finding the meaning of words and symbols in the text. Moreillon (2007) states that reading creates meaning from printed and visual information media. Reutzel et al. (2005) defined reading as a 
process of building comprehension of written essence (text). Reading is understanding, using, evaluating, reflecting on, and engaging with texts to achieve one's goals, develop one's knowledge and potential, and participate in society (OECD, 2018). In conclusion, reading can be defined as the process of getting to know a few words and integrating them into words into sentences and reading structures. It is the communication process between the reader and the author with the language of writing. Therefore, reading can make the essence of the reading. However, reading is not a simple way. It needs work hard from the eyes and brain to comprehend the text.

From the theories above, it can be concluded that reading is a process to comprehend the text to find the general meaning. Read because by reading it can obtain our knowledge. Reading is an active process that requires an excellent idea $f$ practice and skill. In reading, there is an interaction between the reader and the text. In this process, the meanings are conveyed by the writer and the reader are not still the same, which may be different from the other reader reading in the exact text.

\section{a. Micro-and macro-skills of reading}

Reading has micro and macro skills that someone has to acquire. In reading, someone does many skills to make his reading effective. Brown \& Douglas (2004) writes micro and macro skills for reading as presented in the following table

Table. 1 Micro skill and macro skills of reading

\begin{tabular}{|c|c|}
\hline Micro Skills & Skills \\
\hline $\begin{array}{l}\text { Discriminate } \\
\text { among the } \\
\text { distinctive } \\
\text { graphemes and } \\
\text { orthographic } \\
\text { patterns of } \\
\text { English. } \\
\text { - Retain chunks of } \\
\text { the language of } \\
\text { different lengths } \\
\text { in short-term } \\
\text { memory. } \\
\text { Process writing } \\
\text { at an efficient } \\
\text { rate of speed to } \\
\text { suit the purpose. } \\
\text { Recognize a } \\
\text { core of words, } \\
\text { and interpret } \\
\text { word order } \\
\text { patterns and } \\
\text { significances. } \\
\text { Recognize } \\
\text { grammatical } \\
\text { word classes } \\
\text { (noun, verbs, } \\
\text { etc.), systems } \\
\text { (e.g., tense, } \\
\text { agreement, } \\
\text { pluralization), } \\
\text { patterns, rules, } \\
\text { and elliptical } \\
\text { forms. } \\
\text { Recognize that a } \\
\text { particular } \\
\text { meaning may be } \\
\text { forms. }\end{array}$ & 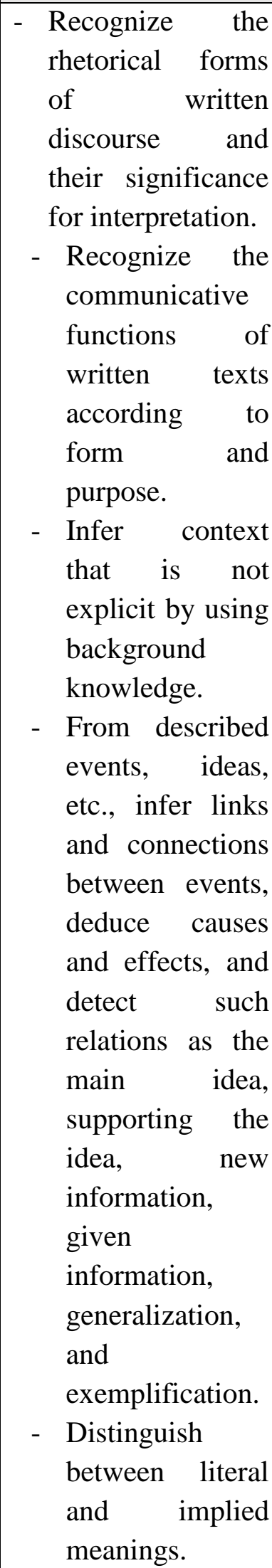 \\
\hline
\end{tabular}




\begin{tabular}{|c|c|}
\hline $\begin{array}{l}\text { Recognize } \\
\text { cohesive devices } \\
\text { in written } \\
\text { discourse and } \\
\text { their role in } \\
\text { signaling the } \\
\text { relationship } \\
\text { between and } \\
\text { among clauses. }\end{array}$ & 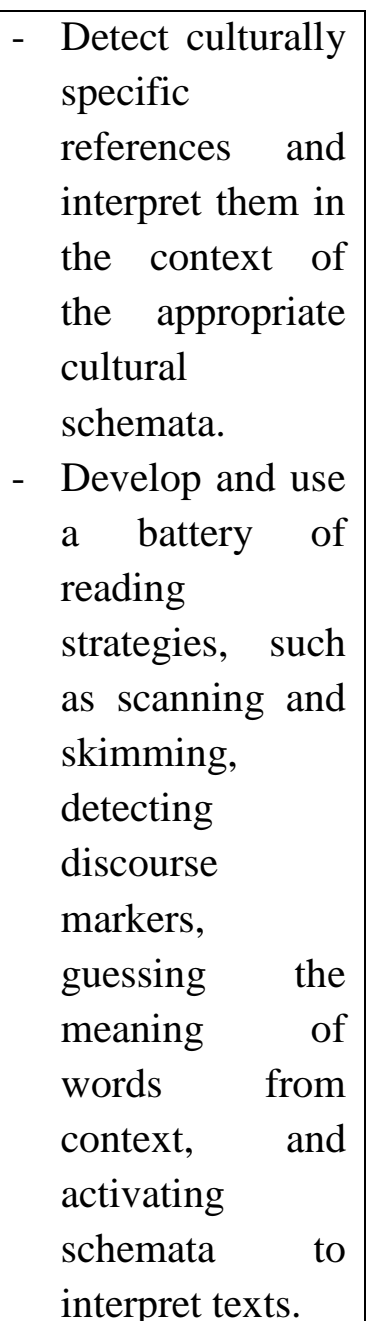 \\
\hline
\end{tabular}

Those micro and macro-skills proposed by Brown are useful and helpful for students reading specific texts. If our students can implement the micro and macro skills in reading, their reading will be compelling. Therefore, based on those macro skills and micro-skills determined, the reading techniques and the reading activities should include those reading macro skills and micro-skills. It aims at helping students comprehend the texts effectively and making them easier to deal with various kinds of texts.

\section{b. Types of Reading}

People read for many purposes, and they must have different purposes when they read something. Because reading purposes are different, there must be some types of reading. Brown \& Douglas (2004) writes some types of reading as follows:

- Perceptive

Perceptive reading tasks involve attending to the components of more enormous stretches of discourse: letters, words, punctuation, and other grapheme symbols. Bottom-up processing is implied.

- Selective

To ascertain one's reading recognition of lexical, grammatical, or discourse features of language within a very short stretch of lexical, grammatical, or discourse features of language within a very short stretch of language, specific typical tasks are used: picture-cued tasks, matching, true/false, multiplechoice, etc. a combination of bottom-up and top-down processing may be used.

- Interactive

Reading is a process of negotiating to mean: the reader brings to the text a set of schemata for understanding it, and taking is the product of that interaction. Top-down processing is typical of such tasks, although some instances of bottom-up may be necessary.

- Extensive

Extensive reading applies to texts of more than a page, including professional articles, essays, technical reports, short stories, and books. Top-down processing is assumed for most extensive tasks.

Because there are many types of reading, it will be good if the teacher can vary the reading purposes in the classroom, 
it can also prevent students from the boredom of reading the same thing all the time. In varying reading texts, a teacher must work harder in searching and choosing appropriate texts for students. Giving students texts close to their age and hobbies is good to enhance their interest in reading.

c. The purpose of reading

The purpose of reading, according to Grabe \& Stoller (2013), has been classified into four purposes, they are:

1. Reading to search for simple information.

2. Its common reading ability, here the readers try to find and scan the specific information. Meanwhile, reading to skim basic reading comprehension and get the critical point of the text.

3. Reading to learn from text

4. It happens in an academic and professional context, and it also requires remembering the main idea and supporting the idea, making a relation with the reader. This activity could bring a more robust inference to remember information.

5. Reading to integrate information, write, and critique text

6. This skill needs more evaluation where the reader decides the information they want. Then it involves the reader abilities such as composing, selecting, and making critiques and inferences from the material.

7. Reading for general comprehension

8. It can be done by fluent reader very fast and automatically in the processing word, and effective coordination in many text processes. d. The Teaching of Reading

Reading is the practice of using text to create meaning. The two keywords here are creating and meaning. If there is no meaning being created, no reading takes place (Andrew \& Johnson, 2008). Someone reads something to gain information. It is rare to find someone read something, but they do not search for some information. Then, when someone reads something, they must get something from what they read. Although probably, they do not read the text carefully, they must know what the text is about. Reading helps someone to create meaning or information.

Reading is a constantly developing skill. Like any skill, we get better at reading by practicing, and conversely, if we do not practice, we will not get better, and our skills may deteriorate (Andrew \& Johnson, 2008). A 5-years-old child has not read yet, but if his parents train him to read, he must be able to read. The first time he learned to read, he might find some difficulties. He cannot be directly able to read fast and accurately. However, when he grows older, when here ads many texts, he will read accurately. An adult also has to practice reading, and if he rarely practices reading, he will find difficulties comprehending the texts. Besides, if he rarely practices reading, it means he lacks knowledge and it may make his thinking skill is low.

Reading is the act of linking one idea to another. Putting ideas together to create a sensible whole is the essential part of the reading (Andrew \& Johnson, 2008). The more texts someone reads, the more knowledge he gets. Probably, when someone reads a text, there are some things that he cannot understand. Then, when he reads other texts related to the texts he had read 
before, he will gain some new information that will make him understand more about a certain topic. Besides, in reading, readers do not have to agree with all the writer says. The readers have the right to agree or disagree with the writer's opinions.

\section{e. PAQRS}

To apply the method in the classroom, the teacher should know exactly what to do. Wormeli (2005) said that the PAQRS method stands for five steps:

1. Preview The teacher will lead the students to identify the main parts of the text. The students could stimulate the prior knowledge before they read the text by considering the text title of the text given. This step is usually done by reading the title or headline.

2. Ask the students to skimming before they read the whole of the text, then the students are asked to write a question about what they have been reviewed, then the students read the whole of the text and summarize the text.

3. Questioning. The students could construct their creative minds by making questions based on the text.

4. Reading. The teacher will give the material (a text) to students. The students can find difficult or new vocabulary in the text while reading by making notes or marks.

5. Summarizing state after that the teacher asks the students to summarize by getting or writing important points. They can summarize paragraph by paragraph.

f. The Advantages of PAQRS Strategy
There are some advantages and disadvantages of using PQRST strategy in teaching reading comprehension. The advantages of PAQRS strategy:

1. The PAQRS strategy helps to enhance students' comprehension of a text. It helped the students arrange the steps of reading. The students would have a good intention to the text because they had the preview before they analyze the whole of the text

2. The benefits of the questioning step led the students to formulate the questions they need to find. This step helped the students to focus and create curiosity toward the text. This motivates the students to read. It made the students find the information details easily. It also made them focus on the aspects that they should find in the text

3. It helped engage students actively and meaningfully in their reading. The students will be actively involved in comprehending the text.

4. This strategy made the students wellplanned in reading in the text. It made the reading process more effective to reach the goals. By knowing this ahead of time, the students able to look for and recognize the most important points when they do read for details. They did not waste time stumbling through the book and finding a starting point.

\section{RESEARCH METHOD}

This research was conducted by using Classroom Action Research (CAR) design. The Classroom Action Research analyzes and evaluates new facts that are happening 
in the class. According to Kemmis \& McTaggart (1998) there are some benefits of classroom action research: (1) thinking critically about what happens in the classroom. (2) Implementing the action to improvements to be possible. (3) Monitoring and evaluating while doing the action to show the improvements. (4) Implementing the flexible approach to the school in the classroom through action.

\begin{tabular}{|c|c|c|}
\hline No & Problems & Note \\
\hline 1 & $\begin{array}{l}\text { The students had bad habits } \\
\text { in reading }\end{array}$ & $\mathrm{S}$ \\
\hline 2 & \begin{tabular}{l}
\multicolumn{3}{l}{ The students easily got bored } \\
during $\quad$ English \\
activities
\end{tabular} & $\mathrm{S}$ \\
\hline 3 & $\begin{array}{l}\text { The students' vocabulary } \\
\text { mastery was low }\end{array}$ & $\mathrm{S}$ \\
\hline 4 & $\begin{array}{l}\text { The teacher dominated the } \\
\text { whole session of the lesson } \\
\text { and give little chance for the } \\
\text { students in expressing ideas }\end{array}$ & $\mathrm{T}$ \\
\hline 5 & $\begin{array}{l}\text { The students did not aware to } \\
\text { express their idea }\end{array}$ & $\mathrm{S}$ \\
\hline 6 & The method was monotonous & M \\
\hline 7 & $\begin{array}{l}\text { Their teacher only focus in } \\
\text { testing students' skill to } \\
\text { answer the question }\end{array}$ & $\mathrm{T}$ \\
\hline 8 & $\begin{array}{l}\text { The teacher did not give } \\
\text { feedback to the students' } \\
\text { work }\end{array}$ & $\mathrm{T}$ \\
\hline 9 & $\begin{array}{l}\text { The teacher did not use any } \\
\text { media to stimulate students to } \\
\text { study. }\end{array}$ & $\mathrm{T}$ \\
\hline
\end{tabular}

In this research, the four phases were conducted in each cycle, namely: (1) Planning, (2) Action, (3) Observation, (4) Reflection. The researcher would start by doing cycle 1 . In cycle 1 the students' scare doesn't increase then the researcher continued to the next cycle by renewing the purpose of steps to solve the problem. The new cycle would improve the teaching decision. If the new cycle was planned and it improves students' ability in reading, the cycle was stopped. If it does not, the next cycle was continuing until the result was reached. The subjects of this study were 37 students in XI (IPS 1) where 18 were females and 19 were males. The instruments used in this research were observation checklist, interview guide, pretest, posttest, documentation. The data collected then analyzed quantitatively and qualitatively.

\section{FINDINGS AND DISCUSSIONS}

Before conducting the auction, the researcher observed and identified the students' problems at class XI IPS 1 of SMA Negeri 19 Makassar in the academic year of 2020/2021. Therefore the researcher continued the observation by interviewing some students of class XI IPS 1 and their English teacher.

\section{Identification of Problem}

Based on the observation at class XI IPS 1 Of SMA Negeri 19 Makassar in the academic year 2020/2021, the researcher found many problems related to the students' reading skills. Those problems are shown in the table below.

Table 2. The Problem Related To The Teaching reading

NB: S: Students

T:

Teacher

M: Method 
Based on the problem found, the researcher decided to change the teaching and learning technique that hope would improve the students' reading skills at class XI IPS 1 of SMA Negeri 19 Makassar. The actions that the researcher planed are:

Table 3. The Action Related to The Problem

\begin{tabular}{|c|c|c|}
\hline No & Action & $\begin{array}{l}\text { The relation } \\
\text { between the } \\
\text { problems and } \\
\text { actions }\end{array}$ \\
\hline 1 & Warming up & 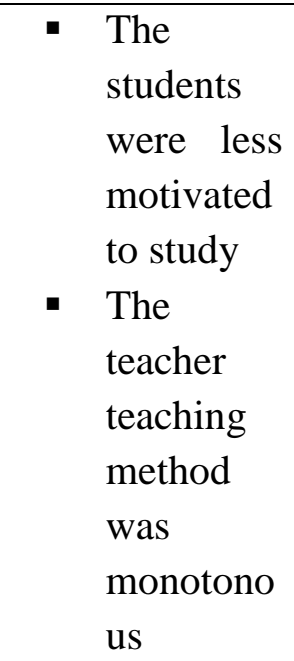 \\
\hline 2 & $\begin{array}{l}\text { Teaching } \\
\text { vocabulary }\end{array}$ & $\begin{array}{l}\text { The } \\
\text { students' } \\
\text { vocabular } \\
\text { y was low }\end{array}$ \\
\hline 3 & $\begin{array}{l}\text { Applying } \\
\text { Preview, Ask } \\
\text { a question, } \\
\text { Read and } \\
\text { Summarize ( } \\
\text { PAQRS } \\
\text { Method }\end{array}$ & 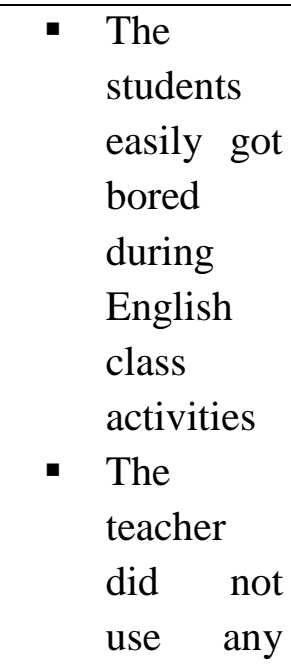 \\
\hline
\end{tabular}

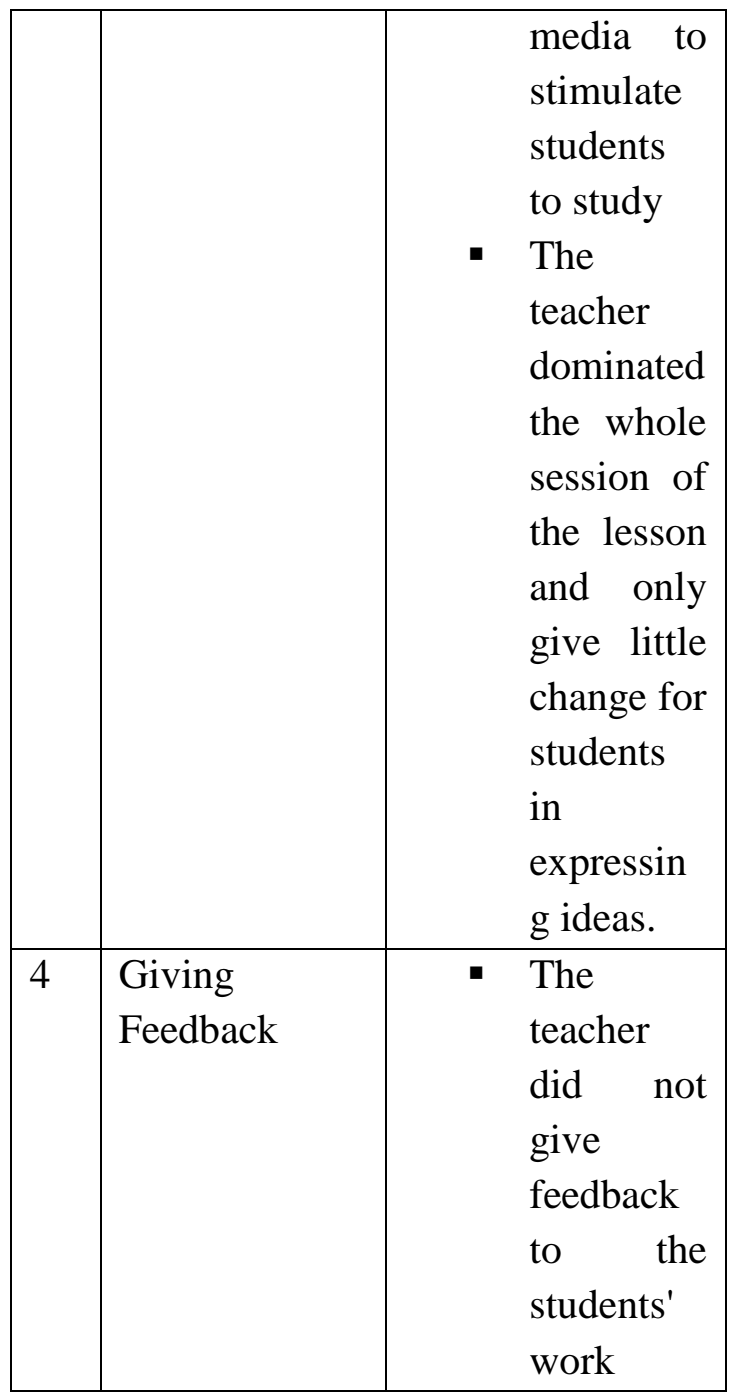

The implementation of Preview, Ask a question, Read and Summarize ( PAQRS ) Method to improve students' reading skill was conducted in two cycles. In every cycle, there are four meetings; three meetings for teaching material and one meeting for the test at the end of every cycle to measure the students' progress. This research was conducted one month from August to September 2021.

Base on the result of the test in cycle one, the searcher concluded that teaching reading through PAQRS Strategy was improved. The improvement was considered not significant since most of the students did 
not pass the maximum grade. While the researcher interviewed some students via WhatsApp to know their obstacles in the first cycle. It can be seen in the following transcript interview:

"In your opinion how learning English use PAQRS Strategy? It is easy to understand?

S1: Yes ma'am

S2: yes ma'am, I like study like that because easy to understood and I also interest with the strategy ma'am."

$10^{\text {th }}$ August 2021

The researcher asked the students that "is this Strategy can help your reading skill or not?" The students said that "it helped because they could study alone and easy to understand.

Based on the students' responses, the researcher found that they were still not enthusiastic in the learning process and they did not have many chances to ask and give their opinion about the material. As the result, the students' reading skill through PAQRS Strategy had not satisfied yet and the researcher continued her research into the cycle 2 .

\section{Cycle II}

This activity was done on Thursday, $17^{\text {th }}$ August 2021. Based on the result of cycle 1, it was not satisfied. The researcher continued to use the PAQRS Strategy. The teacher got the data from the test of cycle II and analyzed the data of pre-test and posttest based on rubric reading in a lesson plan. When the students can reach the standard competence it means that the students are succeed. In this cycle there are $81,8 \%$ of students that can pass the passing grade, so implemented PAQRS strategy in cycle II was succeed.

Table 4. Result of pre-test, post-test cycle 1, and Cycle 2

\begin{tabular}{|c|c|c|c|c|}
\hline No & $\begin{array}{l}\text { Initial of } \\
\text { Students }\end{array}$ & $\begin{array}{l}\text { Pre } \\
\text { test }\end{array}$ & $\begin{array}{l}\text { Posttest } \\
\text { I }\end{array}$ & $\begin{array}{l}\text { Posttest } \\
\text { II }\end{array}$ \\
\hline 1. & $\mathrm{~A}$ & 75 & 78 & 90 \\
\hline 2. & AIM & 60 & 66 & 88 \\
\hline 3. & AIF & 60 & 67 & 82 \\
\hline 4. & $\mathrm{AH}$ & 55 & 76 & 80 \\
\hline 5. & DNAY & 50 & 72 & 80 \\
\hline 6. & FM & 65 & 77 & 88 \\
\hline 7. & FP & 55 & 60 & 80 \\
\hline 8. & GS & 55 & 60 & 85 \\
\hline 9. & $\mathrm{IC}$ & 50 & 60 & 89 \\
\hline 10. & MAM & 50 & 75 & 90 \\
\hline 11. & MNFI & 40 & 65 & 65 \\
\hline 12. & MIS & 55 & 65 & 82 \\
\hline 13. & MTIW & 50 & 60 & 60 \\
\hline 14. & $\mathrm{MF}$ & 55 & 77 & 85 \\
\hline 15. & $\mathrm{MF}$ & 60 & 65 & 65 \\
\hline 16. & MSM & 60 & 78 & 85 \\
\hline 17. & MS & 60 & 65 & 80 \\
\hline 18. & NA & 60 & 75 & 90 \\
\hline 19. & NRAR & 55 & 65 & 65 \\
\hline 20. & PESP & 50 & 62 & 90 \\
\hline 21. & RR & 60 & 76 & 85 \\
\hline 22. & RA & 60 & 65 & 85 \\
\hline 23. & RAS & 55 & 65 & 86 \\
\hline 24. & SL & 40 & 66 & 80 \\
\hline
\end{tabular}




\begin{tabular}{|c|c|c|c|c|}
\hline 25. & $\overline{\mathrm{SAH}}$ & 50 & 66 & 85 \\
\hline 26. & NF & 60 & 66 & 80 \\
\hline 27. & SAHQ & 60 & 65 & 85 \\
\hline 28. & TT & 60 & 66 & 88 \\
\hline 29. & $\overline{\mathrm{UY}}$ & 55 & 65 & 87 \\
\hline 30. & UFIS & 60 & 70 & 80 \\
\hline 31. & YR & 60 & 74 & 74 \\
\hline 32. & YFAP & 50 & 55 & 70 \\
\hline 33. & $\overline{\mathrm{ZZBA}}$ & 60 & 70 & 80 \\
\hline 34. & ZW & 60 & 70 & 85 \\
\hline 35. & ZAP & 55 & 60 & 85 \\
\hline 36. & MA & 40 & 50 & 65 \\
\hline 37 & JA & 60 & 75 & 85 \\
\hline & Total & $\begin{array}{l}\sum x \\
2065 \\
X= \\
55,81\end{array}$ & $\begin{array}{l}\sum \mathrm{x} \\
2492 \\
X=\end{array}$ & $\begin{array}{l}\sum \mathrm{x} \\
2839 \\
X=\end{array}$ \\
\hline
\end{tabular}

From the data above there was an improvement in the students' skills. It could be seen from the average of the test (posttest I, post-test II) that has been increased.

Based on the result of the test in cycle 2 , the researcher felt satisfied because the students had significant improvement from the score they got from test of cycle 1 and test of cycle 2 . They were more active in the teaching and learning process better than the action of cycle 1 . It can be seen in the following transcript interview:
" $\mathrm{R}$ : Did you feel that there were some benefits that you could take in several meeting?

$\mathrm{S} 3$ : yes ma'am of course there were some benefits in several meetings

S2: easy Ma'am, because easy to study and also gave us knowledge for study reading

$\mathrm{S} 1$ : there is many benefits ma'am, because there a many new words who can got in study reading."

The researcher asked that student that "Did you feel that there were some benefits that you could take in several meetings?", the students said that "yes, of course, there were some benefits in several meetings, such as it could increase their knowledge in studying English, they had given many chances to asked during teaching and learning process so that they were more enthusiastic to follow the instruction and then it was different from cycle I, in cycle II that topic was in the form of some questions so they could discuss directly with their friends."

Based on the interview above that the researcher did in the teaching and learning process in the class and from the students' responses, it was obtained that the students are more interesting to study by using PAQRS Strategy while their vocabularies were increased too. Then, the most of students responded to the researcher actively. The researcher concluded that PAQRS Strategy, could improve the reading skill of students, they were more motivated to work in pairs and discuss with their friends.

The implementation of PAQRS Strategy at class XI Ips 1 of SMA Negeri 19 
Makassar showed that there was an (Vivit Rosmayanti, Hasnani, Monalisa) improvement in the students' reading skills significantly. It can be seen by their score that increased step by step, even in the pretest, posttest, and test of cycle 1, most of the students had not passed the maximum standard score, but in the pretest, posttest, and test of cycle 2, the students' reading skill was increased. The result of the students' test as follows:

Table 5. The Data of Test Result Students' Improvement

\begin{tabular}{|c|c|c|c|}
\hline No. & Cycle & Mean & Percentage \\
\hline 1. & Pre-test & 55.81 & $2,70 \%$ \\
\hline 2. & $\begin{array}{c}\text { Post- } \\
\text { test I }\end{array}$ & 67.35 & $18.91 \%$ \\
\hline 3. & $\begin{array}{c}\text { Post- } \\
\text { test II }\end{array}$ & 76.72 & $81.91 \%$ \\
\hline
\end{tabular}

The mean of the students' score in the post-test II was highest, it could be shown that the student's reading skills through PAQRS from 67.35 to 76.72 .

From the table above, the result showed the increase of the student's scores from the pre-test to post-test 1 , post-test 1 to post-test 2 . In the pre-test, the students who passed the KKM were 1 student of 37 students $(2.70 \%)$. In post-test 1 there were 7 of 37 students (18.91\%) passed the KKM. The last, in post-test 2 the students who passed KKN were 30 students of 37 students $(81.91 \%)$.

As the result, the researcher concluded that the students' reading skills at class XI Ips 1 of SMA Negeri 19 Makassar could increase by using PAQRS Strategy.

\begin{tabular}{|c|c|c|c|}
\hline No & $\begin{array}{c}\text { Before the } \\
\text { Actions }\end{array}$ & Cycle 1 & Cycle 2 \\
\hline 1. & $\begin{array}{l}\text { The students } \\
\text { were not } \\
\text { interested in } \\
\text { studying } \\
\text { English } \\
\text { grammar. }\end{array}$ & $\begin{array}{l}\text { There } \\
\text { were only } \\
\text { a few } \\
\text { students } \\
\text { that } \\
\text { interested } \\
\text { to begin } \\
\text { the } \\
\text { teaching } \\
\text { and } \\
\text { learning } \\
\text { process }\end{array}$ & $\begin{array}{l}\text { Most of the } \\
\text { students } \\
\text { were } \\
\text { enthusiastic } \\
\text { to begin the } \\
\text { teaching } \\
\text { and } \\
\text { learning } \\
\text { process }\end{array}$ \\
\hline 2. & $\begin{array}{l}\text { The students' } \\
\text { vocabulary } \\
\text { mastery was } \\
\text { low }\end{array}$ & $\begin{array}{l}\text { Few } \\
\text { students } \\
\text { asked the } \\
\text { researcher } \\
\text { the } \\
\text { meaning } \\
\text { of an } \\
\text { unfamiliar } \\
\text { word in } \\
\text { the } \\
\text { sentences. }\end{array}$ & $\begin{array}{l}\text { Most of the } \\
\text { students } \\
\text { paid } \\
\text { attention to } \\
\text { the words } \\
\text { that have } \\
\text { been taught } \\
\text { by the } \\
\text { researcher. } \\
\text { So that } \\
\text { they could } \\
\text { read the } \\
\text { text } \\
\text { without } \\
\text { asking the } \\
\text { researcher } \\
\text { when they } \\
\text { found } \\
\text { unfamiliar } \\
\text { words. }\end{array}$ \\
\hline
\end{tabular}

From the table above it means that there was an improvement of students" reading skill by using PAQRS strategy. It shown the results of T-test in cycle I it 67.35 and in cycle II it 76.72. It means that there was a significant influence on the cycle I up 
to cycle II. Based on the explanation above, the researcher conclude that using Preview, Ask question, Read, and Summarize (PAQRS) strategy can improve the students" reading skill at class XI Ips 1 of SMA Negeri 19 Makassar.

\section{CONCLUSION}

There is a significant influence of using PAQRS strategy in improving students" reading skill for the second grade students of Senior High School 19 Makassar. It can be seen from the score of test which are increased from the result of the calculation of t-test in two cycles. The t-test of the cycle I is 67.35 and t-test of the cycle II is 76.72. The researcher concludes that there is a significant influence of using PAQRS Strategy in teaching reading for Eleventh Grade students of Senior High School 19 Makassar in the academic year 2020/2021.

\section{SUGGESTION}

The following suggestions addressed to the teacher, the students, and the future researcher are presented:

1. For the teacher the teacher can use PAQRS strategy to improve the students" reading skill. Using PAQRS strategy as a technique in teaching-learning process is enjoyable activity for the students. Moreover, using PAQRS strategy in teaching-learning process is very easy to be applied. It can motivate and make the students easier in reading activity.

2. For the students the students can apply and practice the PAQRS strategy by following the steps. It will help the students to solve their problem in reading and improve their reading skill.
3. For the future researcher the researcher suggests the PAQRS strategy is conducted in larger scope.

\section{BIBLIOGRAPHY}

Nuril Mufidah \& Intan Izha Rohima. "Pengajaran Kosa Kata Untuk Mahasiswa Kelas Intensif Bahasa Arab: Vocabulary Teaching for Arabic Intensive Class." Uniqbu Journal of Social Sciences, vol. 1, no. 1, 2020, pp. 13-24, doi:10.47323/ujss.v1i1.7.

Abd. Ghofur, Isu-isu Pembelajaran Sastra, 1st ed., vol. 1. Pamekasan: Stain pmk press, 2010.

A. Ghofur, "CRITICAL DISCOURSE ANALYSIS OF POWER RELATION ON THE LIFE OF DAVID GALE FILM ON NORMAN FAIRCLOUGH PERSPECTIVE".

A. Ghofur, "How to increase Speaking Ability." https://scholar.google.com/citations?view_op =view_citation $\&$ hl=en\&user=9iU_f90AAA AJ\&cstart $=20 \&$ pagesize $=80 \&$ alert_preview _top_rm=2\&citation_for_view=9iU_f90AA AAJ:bEWYMUwI8FkC (accessed Jan. 11, 2022).

A. Ghofur, "DISCOURSE ANALYSIS: SOME CONCEPTUAL REMARKS ON PRAGMATICS AND RHETORIC," OKARA J. Bhs. Dan Sastra, vol. 5, no. 2, 2011, Accessed: Apr. 04, 2017. [Online]. Available:

http://www.ejournal.stainpamekasan.ac.id/in dex.php/okara/article/view/505

A. Ghofur, "READING OUR SOCIAL WORDS: UTILIZING NOVELS IN TEACHING SOCIOLOGY COURSES," OKARA J. Bhs. Dan Sastra, vol. 6, no. 1, 2012.

A. Ghofur, "ANALISIS RAGAM TUTURAN PARA PELAKU PASAR KABUPATEN PAMEKASAN (Studi Sosiolinguistik Penggunaan Variansi Sapaan)," NUANSA J. Penelit. Ilmu Sos. Dan Keagamaan Islam, vol. 10, no. 2, 2013, Accessed: Apr. 04, 2017. [Online]. Available: http://ejournal.stainpamekasan.ac.id/index.ph p/nuansa/article/view/171/162

A. Ghofur, "HOW SFG INCREASE STUDENTS ABILITY TO PRODUCE AND ANALYSE TEXT MEDIA," OKARA J. Bhs. Dan Sastra, vol. 7, no. 1, 2013.

A. Ghofur, Madurese and English Morphology [The Process \& Diffrences]. Surabaya: Pena Salsabila, 2013. 
A. Ghofur, "Analisis Dekonstruksi Tokoh Takeshi Dan Mitsusaburo Dalam Novel Silent Cry Karya Kenzaburo Oe Perspektif Jacques Derrida," NUANSA J. Penelit. Ilmu Sos. Dan Keagamaan Islam, vol. 12, no. 2, pp. 234257, 2015.

A. Ghofur, "CREATIVE TEACHING," OKARA J. Bhs. Dan Sastra, vol. 6, no. 2, 2017.

A. Ghofur, Representasi Entitas Ghuruh: Makna \& Perilaku bagi Masyarakat Madura Perspektif Interaksionisme Simbolik. Pamekasan: iainmadura press, 2020.

S. Hadi, A. Ghofur, and Humaidy, Moh Ali, Materi Pembekalan Kuliah Pengabdian Pada Masyarakat Perspektif IntegrasiInterkoneksi PAR dan POSDAYA Masjid. Yogyakarta: Pustaka Nusantara, 2014.

J. Jamaluddin and A. Ghofur, "An Analysis of Educational Values in 'Totto-Chan: The Little Girl at the Window' by Tetsuko Kuroyanagi Based on Paulo Freire's Perspective," PANYONARA J. Engl. Educ., vol. 2, no. 1, pp. 31-48, 2020.

M. Gofur, 'Lecturer's Nonverbal Communication attitude in Classroom: Its Meaning for College Sudent," ELITE J., vol. 1, no. 1, pp. 35-42, 2019.

E. rabbiyanty, A. Ghofur, and A. Wafi, "MAXIMIZING THE USE OF WHATSAPP IN ENGLISH REMOTE LEARNING TO PROMOTE STUDENTS'ENGAGEMENT AT MADURA."

https://scholar.google.com/citations?view_op =view_citation $\&$ hl=en\&user=9iU_f90AAA AJ\&alert_preview_top_rm=2\&citation_for_ view=9iU_f90AAAAJ:pqnbT2bcN3wC (accessed Jan. 11, 2022).

A. Asrifan and A. Ghofur, "THE USE OF READING CIRCLES IN INCREASING STUDENTS SPEAKING ABILITY AT THE ELEVENTH GRADE SMK NEGERI 1 PANCARIJANG."

https://scholar.google.com/citations?view_op =view_citation\&hl=en\&user=9iU_f90AAA AJ\&alert_preview_top_rm=2\&citation_for_ view=9iU_f90AAAAJ:9ZIFYXVOiuMC (accessed Jan. 11, 2022).

A. Asrifan and A. Ghofur, "TALK, ACTION, SILENCE, INTERRUPTION AND THEIR IMPLICATIONS IN BUGINESE SOCIETY (SOPPENG REGENCY)." https://scholar.google.com/citations?view_op =view_citation\&hl=en\&user=9iU_f90AAA AJ\&alert_preview_top_rm $=2 \&$ citation_for_ view=9iU_f90AAAAJ:blknAaTinKkC (accessed Jan. 11, 2022).
(Vivit Rosmayanti, Hasnani, Monalisa)

A. Ghofur, "Study On Modalities of Hillary Clinton Debate on United States President Election on Hallidays' Systemic Functional Linguistic Analysis."

https://scholar.google.com/citations?view_op =view_citation $\&$ hl=en \&user=9iU_f90AAA AJ\&alert_preview_top_rm $=2 \&$ citation_for_ view=9iU_f90AAAAJ:M3ejUd6NZC8C (accessed Jan. 11, 2022).

N. Aeni, B. Jabu, M. A. Rahman, H. Ismail, and S. Z. Bin-Tahir, "The Students' Needs in Maritime English Class at Ami Aipi Makassar, Indonesia," J. Lang. Teach. Res., vol. 9, no. 6, pp. 1284-1292, 2018.

Albana, H. H., Marzuki, A. G., Alek, A., \& Hidayat, D. N. (2020). Cohesive Devices in Student's Writing (A Discourse Analysis on Argumentative Text). Jurnal Pendidikan Humaniora, 8(1), 6-11.

Alek, A., Marzuki, A. G., Farkhan, M., \& Deni, R. (2020). Self-Assessment in Exploring EFL Students' Speaking Skill. Al-Ta lim Journal, 27(2), 208-214.

Alek, A., Marzuki, A. G., Farkhan, M., Surahman, D., Daryanto, D., \& Febrianto, S. (2020). Computer Based Testing in Senior High School on National Examination. Indonesian Journal of Learning Education and Counseling, 2(2), 204-210.

Alek, A., Marzuki, A. G., Hidayat, D. N., \& Sari, E. N. A. (2020). A Critical Discourse Analysis of song "Look What You Made Me Do" by Taylor Swift. Eralingua: Jurnal Pendidikan Bahasa Asing dan Sastra, 4(2), 154-161.

Alek, A., Marzuki, A. G., Hidayat, D. N., Islamiati, F. A., \& Raharjo, A. R. (2020). "Why She Disappeared''(A Study of Illeism in Poetic Discourse). Ethical Lingua: Journal of Language Teaching and Literature, 7(2), 447453.

Bin Tahir, S. Z. (2017). Multilingual teaching and learning at Pesantren Schools in Indonesia. Asian EFL Journal, 89, 74-94.

Bin-Tahir, S., Hanapi, H., Mufidah, N., Rahman, A., \& Tuharea, V. U. (2019). Revitalizing The Maluku Local Language In Multilingual Learning Model. INTERNATIONAL JOURNAL OF SCIENTIFIC \& TECHNOLOGY RESEARCH, 8(10).

Bin-Tahir, S. Z., \& Rinantanti, Y. (2016). Multilingual lecturers' competence in english teaching at the university of Iqra Buru, Indonesia. Asian EFL Journal, 5, 79-92.

Bin Tahir, S. Z. (2015). Multilingual behavior of Pesantren IMMIM students in Makassar. Asian EFL Journal, 86, 45-64.

Bin Tahir, S. Z. (2015). The attitude of Santri and Ustadz toward multilingual education at 
Pesantren. International Journal of Language and Linguistics, 3(4), 210-216.

Saidna Z, B. T., Haryanto, A., Syarifuddin, D., \& Yulini, R. (2017). Multilingual Instructional Model of Pesantren Schools in Indonesia. Journal of Language Teaching and Research, 8(6), 1210-1216.

Bin-Tahir, S. Z., Atmowardoyo, H., Dollah, S., Rinantanti, Y., \& Suriaman, A. (2018). MULTILINGUAL AND MONOMULTILINGUAL STUDENTS'PERFORMANCE IN ENGLISH SPEAKING. Journal of Advanced English Studies, 1(2), 32-38.

Bin-Tahir, S. Z., Suriaman, A., \& Rinantanti, Y. (2019). Designing English Syllabus for Multilingual Students at Pesantren Schools. Asian EFL Journal, 23(3.3), 5-27.

TAHIR, S. Z. A. B. (2017). Pengembangan Materi Multibahasa untuk Siswa Pesantren (Doctoral dissertation, Pascasarjana).

Bin-Tahir, S. Z., Atmowardoyo, H., Dollah, S., \& Rinantanti, Y. (2017). Multilingual learning program: pesantren students' perceptions of the multilingual simultaneous-sequential model. JELE (Journal Of English Language and Education), 3(2), 44-53.

Bin Tahir, S. Z. (2015). Multilingual Education in Pesantren Context. Yogyakarta: Deepublish.

Bin-Tahir, S. Z., Hanapi Hanapi, I. H., \& Suriaman, A. (2020). Avoiding Maluku Local Languages Death Through Embedded Multilingual Learning Model: Menghindari Kematian Bahasa Daerah Maluku melalui Model Pembelajaran Embedded Multilingual. Uniqbu Journal of Social Sciences, 1(1), 53-60.

Bin-Tahir, S. Z., Suriaman, A., Hanapi, H., Iye, R., \& Umanailo, M. C. B. (2020). Development of Buru Local Language Conversation.

Bin-Tahir, S. Z. (2015). Multilingual Teaching And Learning At Pesantren.

Tahir, S. Z. B., Atmowardoyo, H., \& Dollah, S. (2018). Belajar Berbicara Multibahasa Uuntuk Santri Pesantren. Deepublish.

Bin-Tahir, S., Hanapi, H., Mufidah, N., Rahman, A., \& Tuharea, V. U. (2019). Revitalizing The Maluku Local Language In Multilingual Learning Model. INTERNATIONAL JOURNAL OF SCIENTIFIC \& TECHNOLOGY RESEARCH, 8(10).

Tuharea, V. U., Tahir, S. Z. B., Ami, I. S. O., \& Rahman, A. (2020). Buru Language Conservation Through Sustainable Mulok Learning In Buru Regency:(Konservasi Bahasa Buru melalui Pembelajaran Mulok Berkelanjutan di Kabupaten Buru). Uniqbu Journal of Social Sciences, 1(2), 49-55.
Bin-Tahir, S. Z., \& Hanapi, H. (2020). Designing the Indonesian Local Language Learning in English Teaching at the Multilingual Classroom Context. Asian EFL Journal, 27(32), 108-120.

Bin-Tahir, S. Z., Tenriawali, A. Y., Umanailo, M. C. B., Hasyim, M., Latjuba, A. Y., \& Abbas, A. (2021). Designing English Teaching Model at the Remote Area Schools of Maluku in Covid19 Pandemic Situation. In Proceedings of the International Conference on Industrial Engineering and Operations Management (pp. 3933-3939).

Tahir, S. Z. B. (2021, March). Designing English Teaching Model at the Remote Area Schools of Maluku in Covid-19 Pandemic Situation. In Proceedings of the 11th Annual International Conference on Industrial Engineering and Operations Management. Universitas Iqra Buru.

Fatimah, A. S., \& Santiana, S. (2017). Teaching in $21^{\text {st }}$ century: Students-teachers' perceptions of technology use in the classroom. Script Journal: Journal of Linguistic and English Teaching, 2(2), 125.

Fatimah, A. S., Santiana, S., \& Saputra, Y. (2019). Digital Comic: An Innovation of Using Toondoo as Media Technology for Teaching English Short Story. English Review: Journal of English Education, 7(2), 101-108.

Fatimah, S. A., S, S., \& Sulastri, F. (2021). JOURNAL OF LANGUAGE AND LINGUISTIC STUDIES. Learner's experience on the use of mobile device for autonomous listening: A narrative inquiry. Journal of Language and Linguistic Studies, 17(1), 193-204

Haucsa, G. M., Marzuki, A. G., Alek, A., \& Hidayat, D. N. (2020). Illocutionary Speech Acts Analysis in Tom Cruise's Interview. Academic Journal Perspective: Education, Language, and Literature, 8(1), 11-19.

Hidayati, A., \& Santiana, S. (2020). Promoting Cultural Awareness through Intercultural Listening Activities. Jurnal Tahuri, 17(2), 5362.

https://doi.org/10.30598/tahurivol17issue2pag e53-62.

Iftitah, A. N., Marzuki, A. G., \& Kuliahana, A. (2020). DEVELOPING VOCABULARY MASTERY THROUGH GUESSING WORDS GAME FOR THE SEVENTH GRADE STUDENTS OF SMP NEGERI 10 PALU. Datokarama English Education Journal, 1(1), 19-37.

Kuliahana, A., \& Marzuki, A. G. (2020). Repetition Technique in an EFL Speaking Class in 
Islamic Higher Education in Indonesia. Academic Journal Perspective: Education, Language, and Literature, 8(1), 20-28.

Marzuki, A. G. (2019). The Implementation of SQ3R Method to Develop Students' Reading Skill on Islamic Texts in EFL Class in Indonesia. Register Journal, 12(1), 49-61.

Marzuki, A. G. (2019). The Roles of School Principal Leadership in Developing English Teachers' Creativities in Palu. Al-Ta lim Journal, 26(3), 267-279.

Marzuki, A. G. (2019). Utilizing Recorded English Dialogues in Teaching English Word Stress to Islamic Higher Education Students in Indonesia. Jurnal Pendidikan Islam, 5(1), 5364.

Marzuki, A. G., \& Kuliahana, A. (2021). Using Language Games to Enhance EFL Students' Speaking Skill in Indonesia. Al-Ta lim Journal, 28(3), 213-222.

Marzuki, A. G., Alim, N., \& Wekke, I. S. (2018). Improving the reading comprehension through cognitive reading strategies in language class of coastal area in indonesia. In IOP Conference Series: Earth and Environmental Science, 156(1), 012050). IOP Publishing.

Marzuki, A. G., Amelia, Y., \& Syam, H. (2021). THE EFFECT OF ANXIETY TOWARD STUDENTS'LEARNING MOTIVATION OF THE ELEVENTH GRADE AT SMAN 4 PALU. Datokarama English Education Journal, 2(1), 49-57.

Marzuki, A. G., Santiana, A. K., Alek, N. F., Darmawati, B., \& Bin-Tahir, S. Z. The Teaching of EFL Vocabulary through Anticipatory Learning Strategy in Islamic Higher Education Context in Indonesia.

Marzuki, A.G. (2016b). Utilizing cooperative learning in islamic college students' classroom, IJEE (Indonesian Journal of English Education), 3(2), 123-139.

Marzuki, A.G. (2017). Developing speaking skill through oral report in an efl class in indonesia, Al-Ta'lim Journal, 24(3), 243-254.

Nashirudin, M., \& Universal, K. H. (2013). Kajian atas Sistem dan Prospeknya di Indonesia. Semarang: El-Wafa.

Hasan, S., \& Nasma, A. (2008). Let's talk about love. Solo: Tiga Serangkai.

Nugroho, B. S., El Widdah, M., \& Hakim, L. (2020). Effect of organizational citizenship behavior, work satisfaction and organizational commitment toward Indonesian School Performance. Systematic Reviews in Pharmacy, 11(9), 962-971.
(Vivit Rosmayanti, Hasnani, Monalisa)

Nashirudin, M. (2019). Talîl al-Ahkâm dan Pembaruan Ushul Fikih. AHKAM: Jurnal Ilmu Syariah, 15(1).

Nashirudin, M., Hasan, M. A. S., \& Ag, M. (2009). Poros-Poros Ilahiyah Perempuan dalam Lipatan Pemikiran Muslim. Surabaya: Jaring Pena.

Nashirudin, M. (2016). Pandangan Majlis Tafsir AlQur'an (MTA) tentang Makanan Halal dan Haram (Kajian Usul Fikih). Al-Manahij: Jurnal Kajian Hukum Islam, 10(2), 235-252.

Amalina, N. H., \& Nashirudin, M. (2017). Analisis Proses Pembelajaran Bahasa Arab pada Tingkat Tsanawiyah di Pondok Pesantren Ta'mirul Islam. Jurnal Tatsqif, 15(2), 173190.

Nashirudin, M. (2017). Fatwa MUI Bidang Ibadah dan Perannya dalam Kehidupan Berbangsa dan Bernegara. International Islamic Conferernce on MUI Studies. Jakarta: MUI, 553.

Nashirudin, M. (2015). Perbedaan dalam Furã ${ }^{\mathrm{TM}} €^{\mathrm{TM}}$ Fiqhiyyah sebagai Akibat Perbedaan dalam Usã $\tilde{T}^{\mathrm{TM}} l$ Al-fiqh. None.

Kasdi, A., Nashirudin, M., Farida, U., \& Praatmana, N. D. (2021). Potential of Kudus as a New International Pilgrimage Destination in Indonesia: Halal Tourism Optimising Local Wisdom. International Journal of Religious Tourism and Pilgrimage, 9(1), 9.

Haris, H., \& Nashirudin, M. (2019). Lombok as an Indonesian halal travel destination. Shirkah: Journal of Economics and Business, 4(3).

Ibrahimy, A. A., Nawawi, N., \& Nashirudin, M. (2020). Kriteria Kafa'ah Dalam Perkawinan: Antara Absolut-Universal Dan RelatifTemporal. Al-Ahkam Jurnal Ilmu Syari'ah dan Hukum, 5(2).

Nashirudin, M. (2017). Interaksi Simbolis Pondok Pesantren Salafi dan Masyarakat. Epistemé: Jurnal Pengembangan Ilmu Keislaman, 12(1), 141-167.

Yahya, I., Nashiruddin, M., \& Aziz, A. (2016). Konsep Jihad 'Abdullah B. Al-mubarak dan Jihad Global. MISYKAT: Jurnal Ilmu-ilmu Al-Quran, Hadist, Syari'ah dan Tarbiyah, 1(1), 147-180.

Nashiruddin, M., \& El Muhammadi, A. (2016). Korelasi kreativitas dan motivasi kerja guru terhadap peningkatan mutu pembelajaran. IJER (Indonesian Journal of Educational Research), 1(1), 51-57.

Nashiruddin, M. (2012). Tinjauan fikih dan astronomis penyatuan matla': menelusuri pemikiran MS Odeh tentang ragam penyatuan matla'. Ijtihad: Jurnal Wacana Hukum Islam dan Kemanusiaan, 12(2), 179192. 
Nashirudin, M. (2012). Kalender Hijriyah Universal, Kajian atas pemikiran MS Odeh dan prospeknya di Indonesia. Disertasi (Program Doktor IAIN Walisongo).

Nashirudin, M. (2011). Sistem penanggalan Hijriah Mohammad Shawkat Odeh. Ijtihad: Jurnal Wacana Hukum Islam dan Kemanusiaan, 11(2), 199-217.

Nashirudin, M., \& Universal, K. H. (2009). Menelusuri Pemikiran Muhammad SyaukatOdeh, makalah disampaikan dalam acara. In Prosidings Seminar Nasional Hilal 2009: Mencari Solusi Kriteria Visibilitas Hilal dan penyatuan Kalender Islam dalam Perspektif Sains dan Syariah.

Santiana \& Fatimah, A. S. (2017). PREZI, CLOUDBASED PRESENTATION, FOR TEACHING: HOW IS IT INTERESTING? Journal of English Education, Literature, and Culture_EduLite, 2(2), 445-456. http://jurnal.unissula.ac.id/index.php/edulite/ar ticle/view/ 1196/125

Santiana, S., Lesmana, D. S., Marzuki, A. G., \& Erizar, E. (2021, December). AN INSIGHT OF ANITALES APPS PERCEIVED BY DIGITAL STORYTELLING STUDENTS. In Proceeding of International Conference on Islamic Education (ICIED) (Vol. 6, No. 1, pp. 23-30).

Santiana, S., Silvani, D., \& Ruslan. (2021). Optimizing LMS CANVAS for Interactive Online Learning Perceived by the Students. Journal of English Education and Teaching (JEET), 5(4), 529-543.

Santiana, S., Pujasari, R. S., \& Fatimah, A.S. (2021). Blended Learning Strategy: Alternatif Pembelajaran Toefl Bagi Guru-Guru Mgmp Non-Bahasa Inggris. Jurnal Inovasi, 1(2020), 144-161.

https://ejournal.unib.ac.id/index.php/jurnalino vasi/article/view/15883.

Widya, T., Fatimah, A. S., \& Santiana. (2020). Students' Feedback As a Tool for Reflection: a Narrative Inquiry of an Indonesian Pre-Service Teacher. Journal of Teaching \& Learning English in Multicultural Contexts (TLEMC), 4(1), $1-11$. http://jurnal.unsil.ac.id/index.php/tlemc/article/ view/1775

Muthmainnah, A. R., Atmowardoyo, H., Salija, K., \& Asrifan, A. (2020). Literary Work as Teaching Materials: A Study of Students and Lecturers Needs Analysis. Solid State Technology, 63(5), 394-407.

Asrifan, A., Muthmainnah, M., Al-Yakin, A., Sahabuddin, C., \& Haedar, H. (2018). THE CAUSE-EFFECT TECHNIQUE IN
TEACHING

RECOUNT

WRITING. JOURNAL OF ADVANCED ENGLISH STUDIES, 1(2), 63-72.

Al Yakin, A., Sahabuddin, C., Rahayu, A., Fitrah, N., \& Arifin, M. (2020). Political Celebrification and Electability: A Study of Political Phenomena Imaging in Election Polewali Mandar District, West Sulawesi, Indonesia. Solid State Technology, 63(5), 632646.

Muthmainnah, M., Asrifan, A., Al Yakin, A., \& Sahabuddin, C. (2019, April). The use of dictogloss technique on ELT classroom: An experiment study of students listening comprehension. In PROCEEDINGS OF THE 65th TEFLIN INTERNATIONAL CONFERENCE (Vol. 65, No. 01).

Asrifan, A., Rinantanti, Y., Tang, S., \& Nadirah, N. (2019). THE 3-DIMENSION PICTURES IN INCREASING THE STUDENTS ABILITY AND INTEREST TO WRITE DESCRIPTIVE COMPOSITION. JOURNAL OF ADVANCED ENGLISH STUDIES, 2(1), 19-30.

Nadilla, T., Ulfah, A. K., Hayati, H., Midesia, S., \& Puspita, D. (2019, November). The Effect Of Leverage And Earning Per Share On Earning Management (A Study Of Companies Listed In Indonesia Stock Exchange). In ICASI 2019: Proceedings of The 2nd International Conference On Advance And Scientific Innovation, ICASI 2019, 18 July, Banda Aceh, Indonesia (p. 164). European Alliance for Innovation.

Ulfah, A. K. (2019). Double Entry Bookkeeping Dalam Akuntansi. J-ISCAN: Journal of Islamic Accounting Research, 1(1), 1-14.

Ulfah, A. K., Fernanda, D., Rahmaniar, R., Mediyanti, S., Agustina, A., Azlina, A., \& Andina, A. (2019, February). Analisis Kemampuan Pembiayaan Keuangan Pemerintah Provinsi Aceh Setelah Penerapan Revisi UU Tentang Otonomi Daerah. In Seminar Nasional Teknologi Komputer \& Sains (SAINTEKS) (Vol. 1, No. 1).

Nurlinda, N., Napitupulu, I. H., Wardayani, W., Azlina, A., Andina, A., Ulfah, A. K., \& Supriyanto, S. (2019). Can E-Commerce Adoption Improve SME's Performance?(Case Studies on Micro, Small and Medium Enterprises with Gojek Services in Indonesia). In Proceedings of the Third Workshop on Multidisciplinary and Its Applications, WMA-3.

Basri, H., Ulfah, A. K., \& Majid, M. (2017). The implementation of good corporate governance (GCG) to improve service quality: the case of state-owned electricity company in Indonesia.

Ulfah, A. K. (2018). KINERJA PERSONIL 
PEMAKAI SISTEM INFORMASI AKUNTANSI SETELAH PELATIHAN SISTEM INFORMASI AKUNTANSI PADA POLDA ACEH. Jurnal Bis-A: Jurnal Bisnis Administrasi, 7(2), 40-46.

Fadhillah, N., Lubis, M. H., Sinar, T. S., \& Setia, E. (2019). Translation strategies used in Indonesian translation of Acehnese poem "Munajat Perempuan Sufi Aceh Pocut di Beutong.". International Journal of Innovation, Creativity and Change, 9(4), 172-182.

Khalsiah, R., Fadhillah, N., Praza, R., \& Desiariawati, N. (2018). An Analysis of Culture Value in Adat Bak Poe Teumeureuhom, Hukom Bak Syiah Kuala, qanun Bak Putro Phang, Reusam Bak Binatara. Indian Journal of Public Health, 9(12).

Lubis, M. H., \& Fadhillah, N. (2020). LOOKING FOR TRANSLATION OF MEANING OF WORDS QALA IN MATAN ARBA IN HADITH. Talent Development \& Excellence, 12(1).

Khalsiah, M., Apridar, N. F., \& Ratri Candrasari, J. (2020). Fiction and Nonfiction Novel: Characteristics Possessed To Allure The Reader. Journal of Talent Development and Excellence, 12(1), 2081-2088.

Lubis, M. H., Fadhillah, N., Candrasari, R., \& Rizki, D. (2020). Fiction and Nonfiction Novel: Characteristics Possessed To Allure The Reader. Talent Development \& Excellence, 12(1).

Aeni, N., Jabu, B., Rahman, M. A., Ismail, H., \& BinTahir, S. Z. (2018). The Students' Needs in Maritime English Class at Ami Aipi Makassar, Indonesia. Journal of Language Teaching and Research, 9(6), 1284-1292.

Aeni, N., Jabu, B., Rahman, M. A., \& Strid, J. E. (2017). English oral communication apprehension in students of Indonesian maritime. International Journal of English Linguistics, 7(4), 158-167.

Aeni, N., \& Panggua, S. (2017, July). A classroom action research at the second year students of indonesian maritime academy aipi makassar. In International Conference on Education, Science, Art and Technology (pp. 131-142).

Arsyad, U., Putranto, B., Aeni, N., Isnan, W., \& Hasnawir, H. (2019). Analysis of biogeophysics characteristics and discharge of Lompo Riaja Atas river and Lompo Riaja Bawah river, Ralla sub watershed. Jurnal Penelitian Kehutanan Wallacea, 8(1), 27-38.

Aeni, N., Fitriani, F., \& Fitri, N. (2019). The Use of Circle Games to improve the Mastery of English Vocabulary of the Indonesian Maritime Academy Students. Journal of Educational Science and Technology (EST), 5(3), 239-244.
(Vivit Rosmayanti, Hasnani, Monalisa)

Marani, I. N., Subarkah, A., \& Wijayanto, A. (2020). The use of computer mediated communication (cmc) In distance learning during covid-19 pandemic: pros and cons. The International Journal of Indian Psychology ISSN, 2348-5396.

Wijayanto, A. (2018). PENGARUH METODE GUIDED DISCOVERY, DAN METODE MOVEMENT EXPLORATION SERTA PERSEPSI KINESTETIK TERHADAP HASIL BELAJAR PUKULAN ATAS BULUTANGKIS PADA MAHASISWA IAIN TULUNGAGUNG. Halaman Olahraga Nusantara (Jurnal Ilmu Keolahragaan), 1(2), 160-176.

Wijayanto, A. (2018). Pengaruh Latihan Renang Teratur Dan Latihan Renang Tidak Teratur Terhadap Kadar Trigliserida Plasma Pada Rattus norvegicus. Biotropic The Journal of Tropical biology, 2(1), 24-40.

Wijayanto, A. (2021). BUNGA RAMPAI Kolaborasi Multidisiplin Ilmu Dalam Menghadapi Tantangan di Era New Normal.

Wijayanto, A., \& Khurniawan, A. W. (2021). BUNGA RAMPAI Strategi Pembelajaran Pendidikan Jasmani Olahraga Dan Kesehatan Selama Pandemi Covid-19.

Mayanto, A., Taufik, M. S., Wijayanto, A., Solahuddin, S., \& Taroreh, B. S. (2021). MODEL PEMBELAJARAAN JARAK PENDEK PADA SISWA SEKOLAH MENENGAH PERTAMA. Jurnal Kejaora (Kesehatan Jasmani Dan Olah Raga), 6(1), 114-120.

Wijayanto, A. Budijanto. 2011. Software Sistem Informasi Penggunaan Energi dan Kebutuhan Kalori. Jurnal IPTEK Olahraga KEMENEGPORA, 13, 1411-0016.

Bin-Tahir, S. Z., Saidah, U., Mufidah, N., \& Bugis, R. (2018). The impact of translanguaging approach on teaching Arabic reading in a multilingual classroom. Ijaz Arabi Journal of Arabic Learning, 1(1).

Febriani, S. R., Widayanti, R., Amrulloh, M. A., \& Mufidah, N. (2020). Arabic learning for elementary school during COVID-19 emergency in Indonesia. OKARA: Jurnal Bahasa dan Sastra, 14(1), 67-80.

Saidah, U., Bin-Tahir, S. Z., \& Mufidah, N. (2018). ARABIC TEACHERS'COMPETENCE: A CASE OF MADRASAH SCHOOLS IN MALUKU. Ijaz Arabi Journal of Arabic Learning, 1(2).

Mufidah, N., Firdaus, U. Z., \& Tahir, S. Z. B. (2018). Model Pengayaan Tutor Bahasa: Studi prelearning pada Shabahul Lughoh di Ma'had Sunan Ampel Al Aly. Jurnal At-Ta'dib Vol, 13(2).

Mufidah, N., \& Rohima, I. I. (2020). Pengajaran Kosa 
Kata Untuk Mahasiswa Kelas Intensif Bahasa Arab: Vocabulary Teaching for Arabic Intensive Class. Uniqbu Journal of Social Sciences, 1(1), 13-24.

Mufidah, N., Suryawati, D., Sa'adah, N., \& Tahir, S. Z. B. (2019). Learning Arabic writing skill based on digital products. Ijaz Arabi Journal of Arabic Learning, 2(2).

Mufidah, N., Salamah, U., Muthoharoh, I., \& Islamy, M. I. (2019). Hybrid learning dalam pembelajaran kosa kata bahasa Arab pada anak berbantuan media Al-Mutho. Al-Mudarris: Journal Of Education, 2(1), 40-52.

Mufidah, N., \& Tahir, S. Z. B. (2018). Empowering E-Learning As An Interactive Teaching For Arabic Learners. Lisanudhad, 5(2), 57-72.

Ummah, S. S., \& Wafi, A. (2017). Metode-Metode Praktis dan Efektif dalam Mengajar Al-Quran Bagi Anak Usia Dini. ACIECE, 2, 121-134.

Wafi, A. (2019). Using Games to Improve Students' Active Involvement in the Learning of English Syntax at IAIN Madura: An Autonomous Learning. OKARA: Jurnal Bahasa dan Sastra, 13(1), 107-120.

Wafi, A. (2011). Using the Think-Pair-Share Strategy to Increase Students' Active Involvement and to Improve Students' Speaking Ability at Islamic the University of Malang.(Thesis). DISERTASI dan TESIS Program Pascasarjana UM.

Rabbianty, E. N., \& Wafi, A. (2021). MAXIMIZING THE USE OF WHATSAPP IN ENGLISH REMOTE LEARNING TO PROMOTE STUDENTS'ENGAGEMENT AT MADURA. LET: Linguistics, Literature and English Teaching Journal, 11(1), 42-60.

Ratnawati, R., Wafi, A., \& Navlia, R. (2020). A Study Of English Songs On Teaching Vocabulary At Kindergaten Students Of Lembaga Pendidikan Islam Bustanuddin Galis Pamekasan. Kiddo: Jurnal Pendidikan Islam Anak Usia Dini, 1(2), 174-186.

Khulaisie, R. N., Hafizh, A. A., Wafi, A., \& Sofia, S. (2019). Achieving Harmony Through Progressive Islamic Dimensions in the Thinking of Abdullah Saeed. Islam Realitas: Journal of Islamic and Social Studies, 5(1), 1-11.

Utami, S., \& Wafi, A. (2020). MANAGEMENT OF EARLY CHILD'S CHARACTER DEVELOPMENT THROUGH HABITUATION AND EXEMPLARY IN KINDERGARTEN. Re-JIEM (Research Journal of Islamic Education Management), 3(2), 216-230.

Fadilah, F., \& Wafi, A. (2020, October). CREATING TEACHER AND STUDENTS-CENTERED ON TEACHING ENGLISH LANGUAGE BY USING ESP APPROACH AT NON-ENGLISH
DEPARTMENT. In Proceedings of the 2nd International Conference on English Language Education (ICONELE) 2020.

Asrifan, A., Vargheese, K. J., Syamsu, T., \& Amir, M. (2020). ESP Course Design: The Need Analysis on Tourism Department in Indonesia Vocational High Schools. Journal of Advanced English Studies, 3(2), 69-77.

Apdy, A. P. R., \& Asrifan, A. (2019, April). The Chinese mime game in teaching vocabulary on EFL classroom. In Proceedings of the 65th TEFLIN International Conference (Vol. 65, No. $01)$.

Puasa, K., Asrifan, A., \& Chen, Y. (2017). Classroom talk in bilingual class interaction. Research in Pedagogy, 7(1), 106-121.

Nadirah, N., Asrifan, A., Vargheese, K. J., \& Haedar, H. (2020). INTERACTIVE MULTIMEDIA IN EFL CLASSROOM: A STUDY OF TEACHING READING COMPREHENSION AT JUNIOR HIGH SCHOOL IN INDONESIA. Journal of advanced english studies, 3(2), 131-145.

Asrifan, A., Zita, C. T., Vargheese, K. J., Syamsu, T., \& Amir, M. (2020). THE EFFECTS OF CALL (COMPUTER ASSISTED LANGUAGE LEARNING) TOWARD THE STUDENTS'ENGLISH ACHIEVEMENT AND ATTITUDE. Journal of advanced english studies, 3(2), 94-106.

Tang, S., Asrifan, A., Chen, Y., Haedar, H., \& Agussalim, M. (2019). The Humor Story in Teaching Reading Comprehension. Journal of advanced english studies, 2(2), 77-87.

Tilome, A. A., Agustang, A., Jasruddin, M. S., \& Asrifan, A. (2020). Social Exchange of Political Elites in the Regional Leader Election of Gorontalo Province, Indonesia. Solid State Technology, 63(5), 521-531.

Suriaman, A., Bin-Tahir, S. Z., \& Usman, S. (2019). Designing Web-Based English Listening Instruction: An Analysis of Indonesian University Student's Needs. Asian EFL Journl. Vol. 23 (3.3), 28-40.

Yusriadi, Y., bin Tahir, S. Z., Awaluddin, M., \& Misnawati, M. (2020). Poverty Alleviation through Social Entrepreneur. Journal of Education, Humaniora and Social Sciences (JEHSS), 3(2), 721-725.

Bin Tahir, S. Z., Iye, R., Tenriawali, A. Y., Karim, Z. Z. Z., \& Umanailo, M. C. B. (2020, March). Cia-cia vocational inventoryization in Buru district. In Proceedings of the International Conference on Industrial Engineering and Operations Management (No. 0, pp. 25092518).

Nagauleng, A. M., Waris, A. M., \& Bi-Tahir, S. Z. 
(2019, April). Psycho pedagogical aspects of EFL learners' performance: a case study at IAIN of Manado. In PROCEEDINGS OF THE 65th TEFLIN INTERNATIONAL CONFERENCE (Vol. 65, No. 01).

Tuharea, V. U., Tahir, S. Z. B., Ami, I. S. O., \& Rahman, A. (2020). Buru Language Conservation Through Sustainable Mulok Learning In Buru Regency:(Konservasi Bahasa Buru melalui Pembelajaran Mulok Berkelanjutan di Kabupaten Buru). Uniqbu Journal of Social Sciences, 1(2), 49-55.

Bin-Tahir, S. Z. (2020). The Role of Local Language in Intercultural Communication among Societies of Buru Island.

Misnawati, A. H., Rahman, Y. Y., Hutapea, R. H., \& Bin-Tahir, S. Z. (2021). Inhibiting Factors (Internal \& External) Implementation of the Family Hope Program (PKH) in Bone Regency. In Proceedings of the 11th Annual International Conference on Industrial Engineering and Operations Management Singapore.

Fatgehipon, A. H., \& Bin-Tahir, S. Z. (2019). Building students state defending awareness in preventing the radicalism. International Journal of Scientific \& Technology Research, 8(10), 3536-3539.

Susiati, S., Tahir, S. Z. B., Hajar, I., \& Tenriawali, A. Y. (2021). Optimalisasi Masyarakat Desa Namlea Dalam Menghadapi Tanggap Darurat Pandemi Covid-19. Journal of Community Dedication and Development (Pengabdian Kepada Masyarakat), 1(1), 50-59.

Misnawati, M., Abd Rasyid, J., Yusriadi, Y., Pengayoman, S. T. I. H., \& Bin-Tahir, S. Z. (2019). The Role of Family Hope Program Actor in Empowering Poor Society (Case Study of Bone Regency) Indonesia. Journal of Public Administration and Governance, 9(2), 359-366.

Reynilda, R., Zainal, H., Rijal, S., Yusriadi, Y., \& Tahir, S. Z. B. (2021, March). Licensing services in the era of the COVID-19 pandemic. In Proceedings of the 11th Annual International Conference on Industrial Engineering and Operations Management (pp. 6322-6329). Universitas Iqra Buru.

Ansar, U. F., Yahya, M., Yusriadi, Y., \& Bin-Tahir, S. Z. Institutional Economic Analysis Of Bugis Merchants In The Inter-Island Trade.

Mulyana, Y., Akbar, Z., Zainal, H., Yusriadi, Y., \& Tahir, S. Z. B. (2021, March). High Domestic Violence during the Pandemic COVID-19. In Proceedings of the 11th Annual International Conference on Industrial Engineering and Operations Management (pp. 6283-6290). Universitas Iqra Buru.

Tahir, S. Z. B. (2021, March). Designing English Teaching Model at the Remote Area Schools of
(Vivit Rosmayanti, Hasnani, Monalisa) Maluku in Covid-19 Pandemic Situation. In Proceedings of the 11th Annual International Conference on Industrial Engineering and Operations Management. Universitas Iqra Buru.

Sadapotto, A., Hanafi, M., Bahang, D., Baharuddin, T., Tahir, S. Z. B., \& Yusriadi, Y. (2021). Investigating Celebritism Phenomenon on Twitter (Semiotics Analysis Trending Topic). Academy of Strategic Management Journal, 20, 1-16. 